\title{
Use of chitosan and polypropylene for the surgical correction of penile deviation in bulls: clinical and histological aspects
}

\author{
Uso de chitosan y polipropileno en la corrección quirúrgica de la desviación \\ del pene en toros: aspectos clínicos e histológicos
}

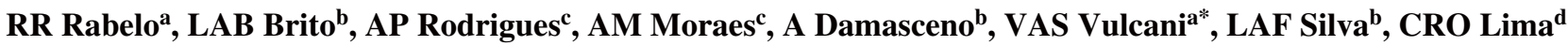 \\ ${ }^{a}$ Curso de Medicina Veterinária, Campus Jatai, Universidade Federal de Goiás, Goiás, Brasil. \\ bEscola de Medicina Veterinária e Zootecnia, Universidade Federal de Goiás, Goiás, Brasil. \\ 'Departamento de Processos Biotecnológicos, Escola de Engenharia Química, \\ Universidade de Campinas, Campinas, São Paulo, Brasil. \\ ${ }^{\mathrm{d} D o u t o r a n d a ~ e m ~ C i e ̂ n c i a ~ A n i m a l, ~ E s c o l a ~ d e ~ M e d i c i n a ~ V e t e r i n a ́ r i a ~ e ~ Z o o t e c n i a, ~ U n i v e r s i d a d e ~ F e d e r a l ~ d e ~ G o i a ́ s, ~}$ \\ Fiscal Agropecuaria Estadual, Jatai, Goiás, Brasil
}

\begin{abstract}
RESUMEN
Los problemas en el tracto reproductivo pueden causar dificultad o incapacidad para copular. La desviación prematura del pene es una causa importante de la impotencia en bovinos machos. El objetivo de este estudio fue realizar una evaluación clínica e histológica de la corrección de la desviación inducida quirúrgicamente en el pene de los toros, mediante la fijación del ligamento apical del pene en la túnica albugínea con implantes sintéticos o biológicos. Veintiún bovinos machos saludables no castrados mestizos, con una libido normal fueron sometidos a la inducción quirúrgica por la extirpación de un fragmento del ligamento apical del pene y su sustitución por una losa de quitosano y una malla de polipropileno después de la confirmación de la desviación del pene. Aunque el examen microscópico reveló que las losas de quitosano han demostrado ser menos irritantes para el tejido receptor. Se observó que todos los animales fallaron en restablecer el eje normal del pene. Por lo tanto, las técnicas quirúrgicas propuestas con implantes sintéticos no eran eficaces para la corrección de la desviación del pene inducida en los toros.
\end{abstract}

Key words: implant, penis, bulls, biomaterials.

Palabras clave: implante, pene, toros, biomateriales.

\section{INTRODUCTION}

The sexual performance of bulls constitutes a significant aspect in extensive bovine production systems. Therefore, problems in the reproductive tract may result in difficulty or inability to copulate, leading to economic losses. Among these diseases, premature penile deviation (PPD) is an important cause of coeundi impotency that affects male bovines of several breeds and different ages.

PPD is clinically characterised by lateral, ventral or spiral deviation with different degrees of intensity, from mild to severe (Rucker et al 2006, Ashdown 2006). Genetic factors such as fragility or malformation of the penile apical ligament are related to this disorder, although the influence of heritability factors has not yet been accurately estimated. However, mechanical injuries to the apical ligament, mainly during copulation, are mentioned as acquired causes of this disease (Eurides et al 1994, Rabelo et al 2008).

In the case of acquired PPD, the main surgical treatment protocols aim to fix the penile apical ligament in the tunica

Accepted: 24.05.2012.

* Campus Jataí, Caixa Postal 3, BR 364, km 192, Zona Rural, CEP 75800000, Jataí, Goiás, Brasil; aloisiosv@ hotmail.com albuginea or to strengthen or replace it with the aid of synthetic or biological implants (Eurides et al 2009). The latter approach has been receiving attention lately due to its lower cost and decreased potential to induce inflammation and rejection response (Fitzgerald 1963, Ashdown 2006, Eurides et al 2007).

Chitosan, a polysaccharide derived from chitin deacetylation by chemical and enzymatic processes, has been used for several in vivo biological applications such as wound healing and tissue repair because of its biodegradability and biocompatibility. Other important reasons to support the use of chitosan as a biomaterial constituent are its low cost and macrophage activation capability as well as its ability to stimulate cell migration and proliferation (Paul and Sharma 2004). Despite these properties, chitosan-based biomaterials have been little studied for use in bull penile deviation management.

Concerning synthetic implants, polypropylene meshes have been used in several species for abdominal cavity repair since 1958. Mild tissue reaction and considerable tension resistance that last for many years are the main reasons behind polypropylene mesh application (Dinsmore et al 2000). However, tissue adherence and rejection response may occur depending on the implantation site, mainly in potentially contaminated areas (Mazzini and Mantovani 1999). 
There are few studies on the clinical and histological behaviour of implants employed for the correction of premature penile deviation in bulls (Eurides et al 1994, Eurides et al 2007, Eurides et al 2009). Tissue substitutes with characteristics such as stability, compatibility with receptor, low cost and easy sterilization and application are quite attractive for conduction of new studies in this area. Thus, the aim of this study was to evaluate clinically and histologically the correction of surgically induced penile deviation in bulls using chitosan slabs or polypropylene meshes and to compare to scarification of the tunica albuginea without implant.

\section{MATERIAL AND METHODS}

In order to prepare the chitosan material, $25 \mathrm{~mL}$ of $3 \%$ chitosan solution (w/w) in 5\% aqueous acetic acid solution (v/v) were added to a dialysis bag that was immersed in $2 \%$ aqueous ammonium sulphate solution $(\mathrm{w} / \mathrm{v})$ for $3 \mathrm{~h}$. After this period, the sides of the bags were cut and the bags remained immersed in the solution overnight. Then the chitosan slabs were removed from the bags, immersed in deionized water for $24 \mathrm{~h}$ and dried at room temperature. The slabs were then sterilized by exposure to $30 \%$ ethylene oxide in $70 \%$ carbon dioxide for $8 \mathrm{~h}$ at $40{ }^{\circ} \mathrm{C}$ and $40-50 \%$ relative humidity according to the methodology employed in Department of Biotechnological Processes, School of Chemical Engineering, University of Campinas, Campinas - Brazil. After sterilization, the slabs were aired with nitrogen three times to remove the residual ethylene oxide.

The prepared slabs were evaluated for maximum uptake capacity and mass loss in water and fetal bovine serum, tensile mechanical properties and morphology basically as indicated by Rodrigues et al (2008).

The maximum uptake capacity was evaluated by immersing samples with known weights $\left(\mathrm{W}_{\mathrm{dry}}\right)$ in $10 \mathrm{~mL}$ of deionized water and in fetal bovine serum at $37^{\circ} \mathrm{C}$. The weights of the wet samples $\left(\mathrm{W}_{\text {wet }}\right)$ were determined after $24 \mathrm{~h}$, and the maximum uptake capacities $\left(\mathrm{C}_{\mathrm{w}}\right)$ were calculated using equation (1). Excess solvent was removed from slab surfaces by gently pressing the samples between two sheets of absorbent paper for 10 seconds prior to weight measurement.

$$
C_{w}=\frac{\left(W_{w e t}-W_{d r y}\right)}{W_{d r y}}
$$

Similarly, the percentages of slab mass loss were determined by immersing dried samples with known weights $\left(\mathrm{W}_{\text {initial }}\right)$ in distilled water and in fetal bovine serum at $37^{\circ} \mathrm{C}$ for seven days. After this period, the samples were dried at $37^{\circ} \mathrm{C}$ for $24 \mathrm{~h}$ and the weight of the samples $\left(\mathrm{W}_{\text {final }}\right)$ was determined. The mass loss $(\mathrm{M})$ was calculated according to equation (2).

$$
M(\%)=\left(\frac{W_{\text {initial }}-W_{\text {final }}}{\text { initial }}\right) x 100
$$

The tensile mechanical properties of the slabs were analysed with a universal testing machine employing a cell load of nine pound-force (lbf), a gauge length of $30 \mathrm{~mm}$ and a crosshead speed of $10 \mathrm{~mm} / \mathrm{min}$.

The morphology of the samples was evaluated using a scanning electronic microscope coupled to the Leo UIF series 400 software. The samples were placed on appropriate stubs and sputtered-coated with an ultrathin layer of gold (92 ^) in a coating apparatus.

Twenty-one healthy, uncastrated, crossbred (Bos indicus $x$ Bos taurus) male bovines, aged between 18 and 20 months and having normal libido determined by tests of sexual behaviour and service capability, were selected for this study. The parameters considered in testing for normal libido were copulation capability with or without guidance, flehmen reflex, licking, pelvic movements and masturbation (Parkinson 2004). The animals originally had no genital abnormalities which could negatively affect the copulation.

This study was carried out at a farm located in the state of Goiás, Brazil, between September 2007 and February 2008. The experimental protocols were designed in accordance with the ethics and welfare recommendations of the Brazilian College of Animal Experimentation (COBEA) and were approved by the Committee of Ethics in Animal Experimentation of the Goiás Federal University in October, 2006 (n. 073/2006).

The bulls were sedated with $2 \%$ xylazine at $0.05 \mathrm{mg} / \mathrm{kg}$ associated with $1 \%$ acepromazine hydrochloride at $0.05 \mathrm{mg} / \mathrm{kg}$, both by intravenous injection, followed by loco-regional blockade of the pudendal and hemorrhoidal nerves. Physical restraint was performed in right lateral recumbency.

Thus, the penile free extremity was exposed for cleaning and antisepsis of the gland and internal preputial mucosa with polyvinylpirrolidone iodine solution. Subsequently, the other extremity of the penis was compressed for preventive homeostasis and a $5 \mathrm{~cm}$ long longitudinal incision was made on the left dorsolateral surface of the penile tegument, starting $2 \mathrm{~cm}$ from the caudal extremity of the gland column. Then the penile apical ligament was isolated and a $2 \mathrm{~cm}$ long segment was removed. The penile tegument was sutured with no. 00 chromic catgut string in a simple interrupted pattern (Eurides et al 2007). Three injections of long acting oxytetracyclin suspension $(200 \mathrm{mg} / \mathrm{mL})$ at a $20 \mathrm{mg} / \mathrm{kg} \mathrm{q} 48 \mathrm{~h}$ intramuscularly were administered. Intrapreputial cleaning with $0.7 \%$ chlorexidine solution was carried out once a day for ten consecutive days. Every three days, the penis was exposed for clinical evaluation of the wounds and also to avoid formation of adhesion. This procedure was performed using loco-regional blockade of the pudendal and hemorrhoidal nerves by administration of lidocaine 
hydrochloride and transrectal massage of the prostate and seminal vesicle.

Forty-five days after the surgery, sexual behavior and service capability tests were done to visually assess the presence, type and degree of penile deviation. The degree of penile deviation was graded as mild, moderate or severe based on Cardoso et al (2010). According to this grading system, the axis deviation was considered mild when the angle ranged between 5 to $20^{\circ}$, moderate between 20 and $40^{\circ}$ and severe above $40^{\circ}$, as shown in figure 1.

After confirmation of the type and degree of penile deviation, the animals were randomly divided into three experimental groups of seven animals each (G1, G2 and G3), independently of the type and degree of penile deviation. Preoperative care and anesthetic protocol were similar to those previously described. After exposure of the penis, an $8 \mathrm{~cm}$ long longitudinal incision was made in the penile tegument in the middle third of the dorsal surface of the glans, approximately $1.0 \mathrm{~cm}$ from the caudal extremity of the gland column and ending $1.0 \mathrm{~cm}$ before the insertion of the internal sheath of the prepuce. After incision of the tegument, a space was created with blunt dissection of surrounding connective tissue to insert the implants replacing the apical ligament of the penis (Fitzgerald 1963).

A sterile polypropylene mesh was implanted under the penile albuginea of each of the G1 bulls (figure $2 \mathrm{a}$ ). The penile tegument was sutured with chromic catgut no. 00 in a simple interrupted pattern. The animals in the G2 group were implanted with one chitosan slab each (figure $2 \mathrm{~b}$ ). Both biomaterials were $10 \mathrm{~cm}$ in length and $1 \mathrm{~cm}$ in width, but while the polypropylene mesh was $0.2 \mathrm{~mm}$ in thickness, chitosan slabs were around $4 \mathrm{~mm}$. Before implantation, the slabs were hydrated in Ringer lactate solution at room temperature for 12 hours. The implants were not attached to the tunica albuginea of the penis. The animals allocated to G3, considered the control group, received the same surgical procedures as the G1 and G2 groups, except for the application of an implant (figure $2 \mathrm{c}$ ). In these animals, scarification of the tunica albuginea without implant was performed, to ensure that spontaneous penile deviation correction would not occur from the healing process. In all groups, the procedures during the postoperative period were similar to those described for the previous stage, except for the preputial washing period, which in this case was extended to 15 days. For adhesion prevention and clinical evaluation of the surgical incision of the free extremity of the penis was exposed every three days in the first month and at ten-day intervals until the end of the evaluation period, which ended two months after the implantation.

Scores were established for clinical evaluation of the implant sites. It was considered the extent of swelling and redness measured by a caliper (Rabelo et al 2005a, Rabelo et al $2005^{\text {b }}$ ). The intensity of inflammation was graded as

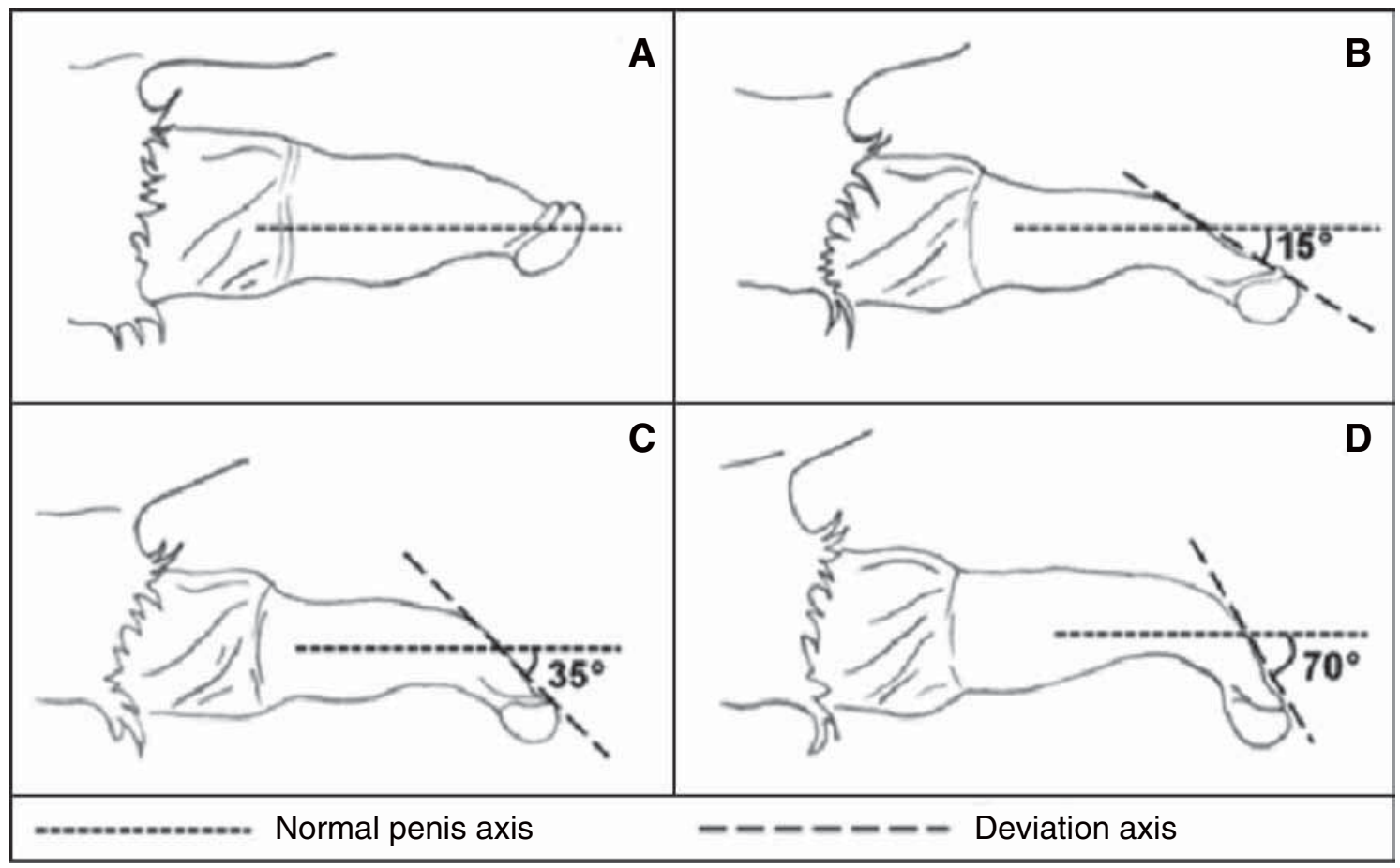

Figure 1. Scheme of different degrees of ventral penile deviation (PD) of male bovines. (A) normal penis; (B) mild deviation $\left(\mathrm{PD}<20^{\circ}\right)$; $(\mathrm{C})$ moderate deviation $\left(20^{\circ}<\mathrm{PD}<40^{\circ}\right)$; (D) severe deviation $\left(\mathrm{PD}>40^{\circ}\right)$.

Esquema de los diferentes grados de desviación ventral del pene (PD) de toros. (A) del pene normal; (B) la desviación leve $\left(\mathrm{PD}<20^{\circ}\right)$; (C) Desviación moderada $\left(20^{\circ}<\mathrm{PD}<40^{\circ}\right)$; (D) Desviación grave $\left(\mathrm{PD}>40^{\circ}\right)$. 


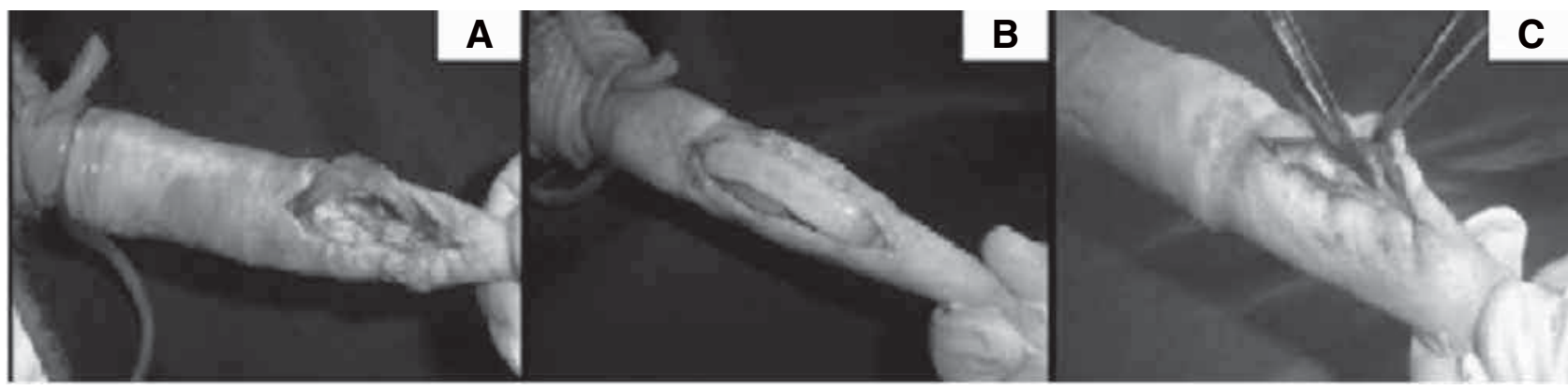

Figure 2. Penile deviation correction in bulls. (A) application of polypropylene mesh; (B) application of chitosan slab and (C) control (no implant used).

Corrección de la desviación del pene en los toros. (A) la aplicación de malla de polipropileno; (B) la aplicación de la losa del quitosano y (C) de control (sin implante).

0 (absent), 1 (mild swelling and redness) - swelling and redness less than or equal to $0.5 \mathrm{~cm}, 2$ (moderate swelling and redness) - swelling and redness greater than $0.5 \mathrm{~cm}$ and smaller than $1 \mathrm{~cm}, 3$ (severe swelling and redness) - swel ling and redness greater than $1 \mathrm{~cm}$.

For granulation tissue and surgical incision dehiscence, the responses were classified as 0 (absent), 1 (present within a range less than $30 \%$ of the surgical incision length), 2 (present within a range between $30 \%$ and 60\%) or 3 (present within a range larger than $60 \%$ ). Abscess, fistula and rejection of the implants were considered as 0 (absent) and 1 (present). At the end of the 60-day period after implantation, sexual behaviour and service capability tests were performed again for bulls in all groups in order to evaluate the efficiency of the experimental protocols used for the correction of penile deviation.

The final area of consideration during our trial consisted of histological evaluation of the penile tissue at the implant site. The animals were slaughtered and the external genitalia was collected, packed and sent under refrigeration for histologic processing. Two $\mathrm{cm}$ thick fragments of the penis at the implant site were fixed in $10 \%$ buffered formalin for 48 hours. After that, the tissue sections were washed with solution of sodium chloride $0.9 \%$ for fifteen minutes and dehydrated in increasing concentrations of ethanol from $70 \%$ to absolute, followed by clarification in xylene and paraffin-embedded. Tissues were sectioned in $5 \mu \mathrm{m}$ thick samples in a rotary microtome and stained with hematoxylin and eosin (HE) (Luna 1968).

The presence of inflammatory infiltrate, angiogenesis, giant cells, fibroblasts, eosinophils and collagen was recorded. Inflammatory reaction was characterised as acute (presence of polymorphonuclear infiltration) or chronic (presence of mononuclear infiltrate). The severity was considered mild when there was less than $25 \%$ inflammatory infiltration, moderate between $25 \%$ and $50 \%$ and accentuated above 51\% (200 X). For characterization of angiogenesis, intensity was cocnsidered mild, moderate or accentuated when blood vessels were present in an area less than 25\%, between 25\%-50\% and above 50\% (200X magnification), respectively. Giant cells, eosinophils, fibroblasts and collagen fibrils were classified as absent or present. The results obtained were analyzed by descriptive statistics (Steel 1980).

\section{RESULTS AND DISCUSSION}

The results obtained for the surgical induction of penile deviation are summarized in table 1 for animals randomly divided into three groups (G1, G2 and G3). The typical aspects of the penile deviations observed are shown in figure 3.

After surgical induction the animals showed two types of penile deviation, ventral and right lateral. Thirteen animals (62\%) showed right lateral deviation. Thirty-eight percent of the animals developed a mild degree of penile deviation, while $43 \%$ and $19 \%$ had moderate and severe degrees of penile deviation, respectively. Only animals with a mild deviation degree were able to copulate, but with difficulty.

With regard to the preparation of the chitosan slabs it was observed that the absorption was up to $2.91 \pm 0.22$ grams of water per gram of dried sample and $2.57 \pm 0.20$ grams of fetal bovine serum per gram of sample, and mass losses in the same fluids equal to $5.84 \pm 2.18 \%$ and

Table 1. Deviation types and degrees observed 45 days after surgically inducing penile deviations in bulls $(n=21)$.

Tipos de desviación y los grados observados 45 días después de la inducción quirúrgica de las desviaciones del pene en toros $(\mathrm{n}=21)$.

\begin{tabular}{cccccc}
\hline \multirow{2}{*}{ Group } & \multicolumn{2}{c}{ Deviation type } & \multicolumn{3}{c}{ Deviation degree } \\
\cline { 2 - 6 } & Ventral & Right lateral & Mild & Moderate & Severe \\
\hline G1 & 4 & 3 & 1 & 4 & 2 \\
G2 & 6 & 1 & 3 & 3 & 1 \\
G3 & 3 & 4 & 4 & 2 & 1 \\
\hline
\end{tabular}




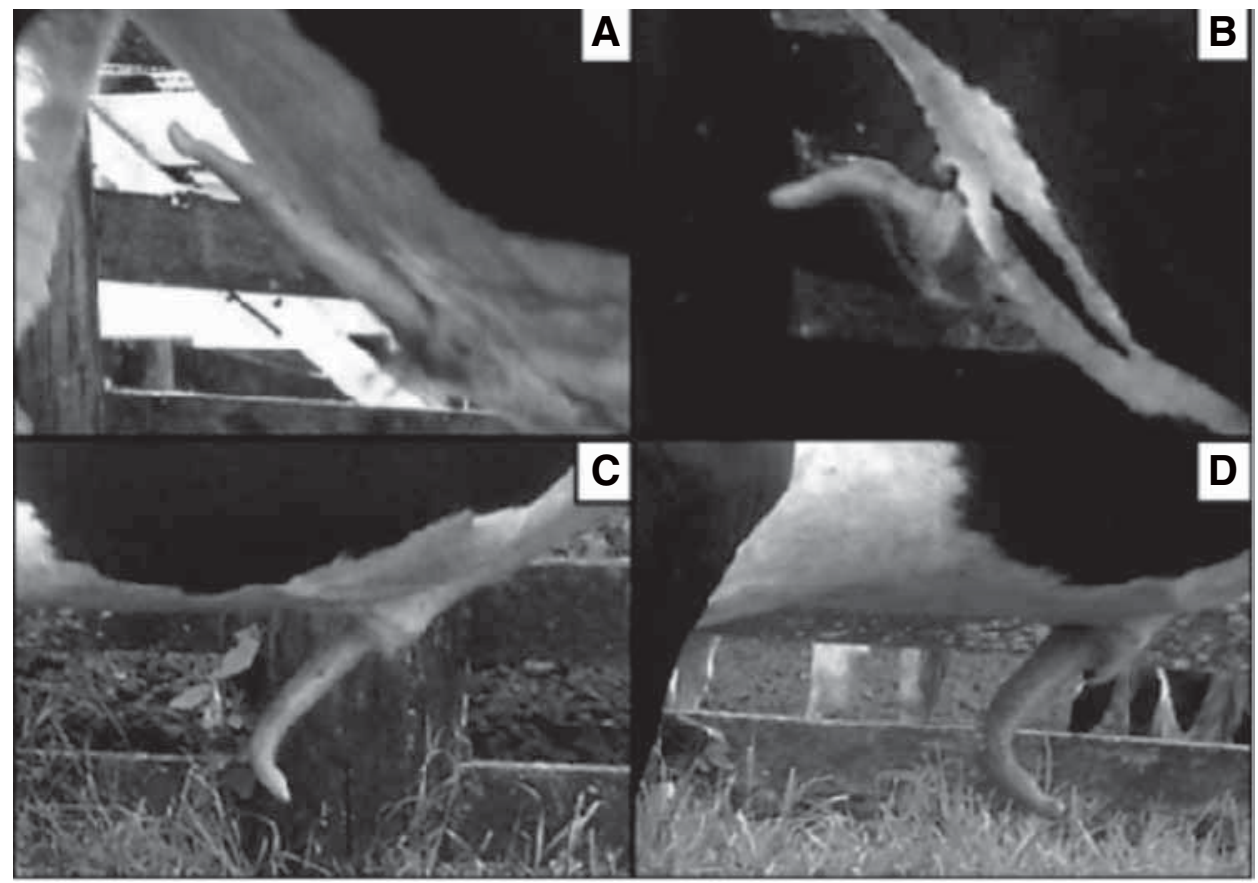

Figure 3. Typical appearance of the different types and degrees of penile deviation in bulls. (A) normal penis; (B) mild; (C) moderate and (D) severe ventral penile deviations.

Apariencia típica de los tipos y grados de desviación del pene en toros. (A) pene normal; (B) leve; (C) moderado y (D) graves desviaciones del pene ventral.

$39.65 \pm 3.95 \%$, respectively, when exposed to water and fetal bovine serum at $37^{\circ} \mathrm{C}$ for seven days. The amount of liquid absorbed regardless of the type was not too high, but degradation was significantly greater for samples in serum than for those in water. The average tensile strength of the hydrated slabs, their elongation at break and modulus were $0.16 \pm 0.04 \mathrm{MPa}, 33.80 \pm 11.13 \%$ and $0.83 \pm 0.22 \mathrm{MPa}$, respectively, which characterises the slabs as biomaterials with relatively low mechanical resistance. The typical morphology of the dense slabs (moderately rough, but highly fractured surface; nonporous) is shown in figure 4 .

In general, no difficulties were experienced in the handling of the biomaterials used as implants for the correction of penile deviation. However, application of the chitosan implants was more laborious due to their smooth, slippery and brittle characteristics.

All G1 (polypropylene mesh) bulls showed a mild inflammatory response during the first 15 days after implantation. Thereafter, five (71.4\%) animals showed grade 2 inflammation. Granulation tissue of grades 1 and 2 were observed in six (85.7\%) and one animal, respectively. At day 24, the inflammatory reaction was worse, as a grade 2 was observed in four $(57.2 \%)$ and a grade 3 in three $(42.8 \%)$ bulls. Granulation tissue of grades 1, 2 and 3, was observed in two (28.6\%), four (57.2\%) and one (14.3\%) bulls, respectively. Grade 1 incision dehiscence, fistula and implant rejection were observed in one (14.3\%) animal for each type of response. On day 30 post-operation, five (71.4\%) bulls showed implant rejection. Among these, grade 1 and 2 dehiscence was observed in two (28.6\%) and three (42.8\%) bulls, respectively (figure 2). On day 45 , no changes in these clinical parameters were observed.

In G2 (chitosan slab), grade 1 inflammatory reaction was detected in all animals on the ninth day. On day 15, inflammation remained at the same level, except in one (14.3\%) animal that had a grade 2 score. On day 24 , signs of inflammation were no longer observed. Grade 1 granulation tissue was observed in three $(42.8 \%)$ and of grade 2 in two (28.6\%) bovines. Regarding the other parameters, no complications were observed. Implant integration had been completed in all animals by the end of the observation period (figure 5).

Similarly as observed in G2, grade 1 inflammatory reaction was observed in all animals in G3 (control group). On day 15 , five ( $71.4 \%$ ) bulls showed the same degree of inflammation. Grade 1 granulation tissue was observed in three (42.8\%) animals in this period. However, healing was complete and no changes in conditions were detected until the end of the observation period.

Sexual behaviour and service capability tests were performed 60 days after penile deviation surgery and indicated that independently of the type and degree of penile deviation, none of the animals had corrected or minimized penile deviation. However, libido remained unchanged in all groups. 

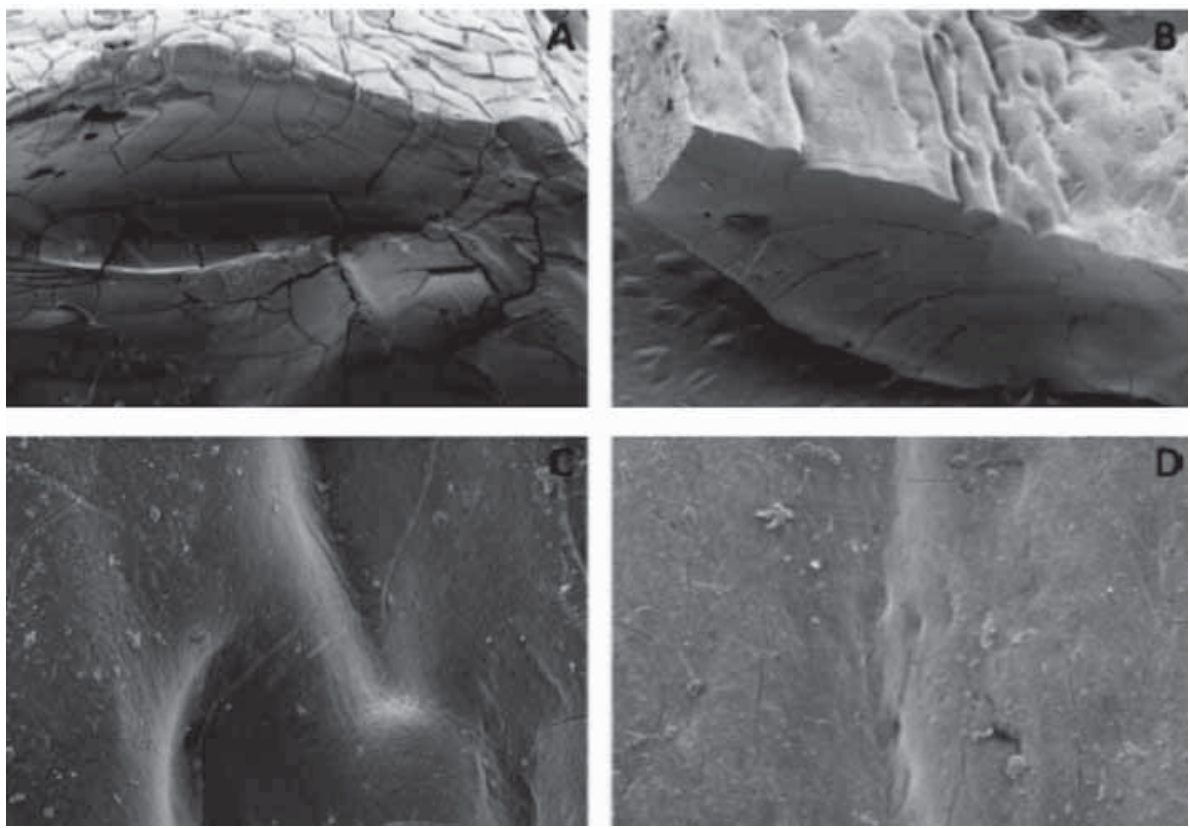

Figure 4. Transmission electron microscopy (TEM) of cross section of chitosan slabs (A) x 200 and (B) x 100. Surface of chitosan slabs (C) x 1,000 and (D) x 500 .

Microscopía electrónica de transmisión (TEM) de la sección transversal de las losas de quitosano (A) x200 y (B) x 100. La superficie de las losas de quitosano (C) x1000y (D) $500 \mathrm{x}$.

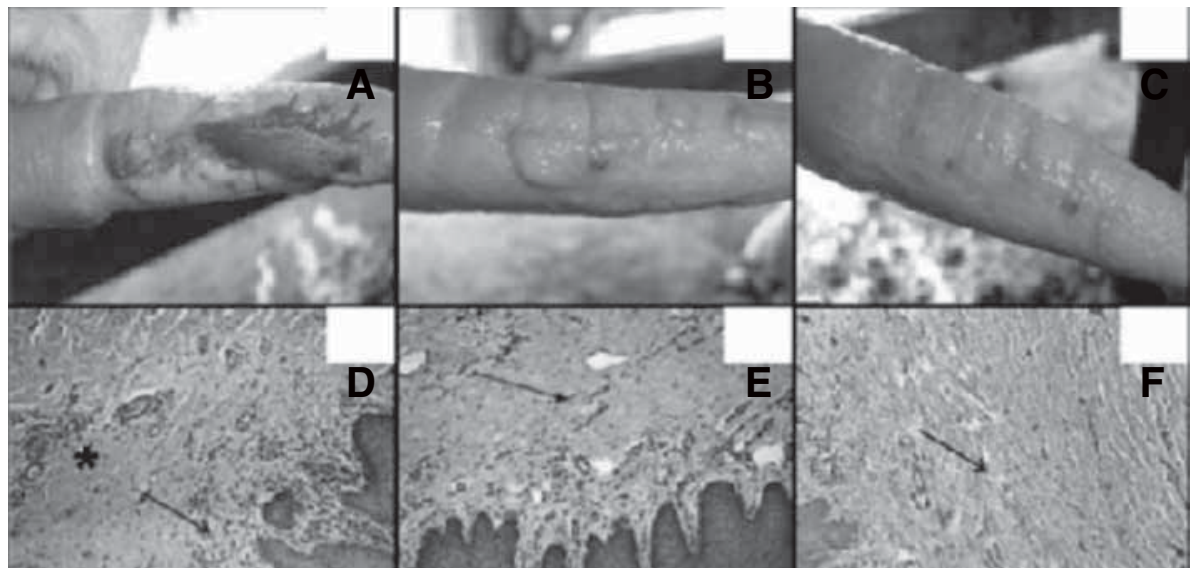

Figure 5. Typical clinical and histological characteristics 45 days after the penile deviation correction procedure in bulls. Aspect of penis after: (A) application of polypropylene mesh; (B) application of chitosan slab and (C) control (no implant used). Microscopy examination (100x) of implantation sites with HE in bulls showing respectively: (D) severe; (E) moderate and (F) no lymphoplasmocytic infiltration (arrow). Collagen and angiogenesis present in variable degrees (asterisk) (HE, 100x).

Típicas características clínicas e histológicas de 45 días después del procedimiento de corrección de la desviación del pene en los toros. Aspecto de pene después de: (A) la aplicación de malla de polipropileno, (B) la aplicación de la losa de quitosano, y (C) de control (sin implante). Examen microscópico (100x) de lugares de implantación de la ES en los toros que muestran, respectivamente: grave (D), moderado (E) y (F) la infiltración ausente linfoplasmocitaria (flecha). Colágeno y angiogénesis presente en grados variables (asterisco) (HE, 100x). 
Histological findings in G1 were characterised by the presence of severe inflammatory infiltrate in the penile tegument of seven animals (100\%), moderate angiogenesis in six $(85.7 \%)$ bulls and the presence of fibroblasts and collagen in all the samples collected from this region (figure 5). No implant fragments were observed in the tunica albuginea however, on the edge of the implantation site, severe chronic inflammatory infiltrate was observed in five (71.4\%) bulls. In the remaining animals (28.6\%), inflammation was classified as moderate. Eosinophilic reaction was observed in six (85.7\%) cases and giant cells and fibroblasts were present in all the animals.

In $\mathrm{G} 2$, there was lymphocytic infiltrate in subcutaneous region in five (71.4\%) samples. Of these, four (80\%) were mild and one (20\%) was severe. Fibroblasts and collagen could be seen in all the animals. In the same region, angiogenesis was classified as severe in four $(57.1 \%)$ and moderate in three (42.9\%) bulls (figure 5). Generally, the microscopy evaluation of the tunica albuginea revealed mild chronic inflammatory infiltrate in six $(85.7 \%)$ bulls. Only one $(14.3 \%)$ animal had no inflammatory reaction. Fibroblasts, collagen and the absence of implant fragments were the main findings, except in one animal, that had a fragment of the chitosan slab in the region of the tunica albuginea. However, no eosinophilic or mononuclear infiltrate was observed along this fragment.

In G3 (the control group), mild chronic inflammatory infiltrate was detected in the subcutaneous tissue and tunica albuginea. Mild angiogenesis was present in five (71.4\%) bulls. In all the animals, mild tissue disorganization was observed at the scarification site, which showed a weaker appearance than normal tissue (which is usually denser). Fibroblasts and collagen were observed. Eosinophils and giant cells were not observed.

The successful experimentally induced penile deviation through removal of a fragment of the penile apical ligament of the bulls highlights the importance of this structure in the pathogenesis of this disease (Eurides et al 2007). A higher incidence of right lateral (62\%) versus ventral (38\%) deviation, as observed in this study, was also previously reported for the experimental induction of penile deviation by means of a section of the apical ligament (Eurides et al 1994). However, in others studies it was observed that only sectioning the ligament was ineffective in surgical induction of penile deviation (Rabelo et al 2008, Cardoso et al 2010). The occurrence of fibroplasia after surgery in this case could be related to regeneration and functional recovery of the penile apical ligament. Removal of a portion of this structure was shown to be essential for experimental induction of the problem. Thus, under natural conditions other predisposing factors are probably associated with the pathophysiology of penile deviation.

The higher incidence of inflammation, granulation tissue, fistula and wound dehiscence, and the rejection and expulsion of the implant in five (71.42\%) bulls in G1, demonstrated that the use of polypropylene mesh as an implant option was unsuccessful. In addition, penile deviation was not corrected in any of the tested animals in this study. Maybe the inherent antigenic characteristic of the penile tissue associated with potential contamination of the internal preputial sheath, as potentially contaminated areas may exacerbate the implant inflammation and antigenicity characteristics, resulting in its rejection (Richa 1987, Babensee et al 1998).

Regarding the microscopic findings observed in the G1, chronic inflammatory reaction characterised by lymphocytic infiltration and granulation tissue can be explained by the length of contact time between the irritant material and the receptor site. Chronic inflammation characterised by the presence of macrophages phagocytosis of foreign material and induced granulation tissue formation was noted. Foreign body reaction with the presence of giant cells, fibroplasia and monocytic infiltration surrounding the mesh filaments are common findings when implants such as polypropylene meshes are used (Rucker et al 2006). Lymphocytic infiltration was observed in specific immune response and type IV chronic hypersensitivity reaction, both indicative of rejection (Spencer 2003).

Eosinophilic reaction surroundings the mesh was observed even after implant expulsion. This observation suggested that the antigenicity of the synthetic material strongly contributed to its rejection, resulting in expulsion of the mesh. Eosinophils act in the remodeling stage and in the latter stages of reparation (Todd et al 2001). Thus, it can be assumed that eosinophils may be related to growth factor production. Furthermore, eosinophils and mononuclear infiltrate may also indicate a possible hypersensitivity reaction that exacerbates foreign body reaction, contributing to the rejection of the implant as reported in this study.

Chitosan slabs did not correct the penile deviation in any of the bulls in G2, however implant complications such as rejection and expulsion were not observed. Histological examination revealed chitosan implant degradation/absorption in all the animals without foreign body reactions. Remnants of a chitosan slab were found in only one sample. The biodegradability and biocompatibility observed in the present study are common characteristics of chitosan, also reported by others (Harish and Tharanathan 2007). Chitosan-induce angiogenesis has been previously reported, but in tectonic keratoplasty in rabbits, ranging from moderate to severe (Rucker et al 2006).

Microscopically, the receptor area of G1 and G2 appears to share similar features. Both were able to induce the replacement of the loose connective tissue by dense connective tissue between the apical ligament and the tunica albuginea.

The substitution of the loose tissue by dense tissue was considered the main factor, among other reasons, in repairing of penile deviation (Cardoso et al 2010). This event was observed whit the use of autologous tendon of the superficial flexor muscle and autologous auricular 
cartilage in bulls to repairing penile deviation (Eurides et al 2007, Eurides et al 2009).

Even though the polypropylene and chitosan slabs encouraged replacement of the connective tissue around the ligament, they were not effective in reestablishing the normal anatomic aspect of the bulls' penises. The biological implants such as chitosan cause milder inflammatory reactions in relation to synthetic implants, but have rapid biodegradation. It is believed that the crosslinking of the material or its use in a composite to prolong its action on the receptor site would be a promising alternative.

In G3, despite the presence of fibroblasts and collagen in the scarification area, there was not enough fibroplasia to correct the penile deviation being necessary the use of implants.

We can conclude that the scarification of tunica albuginea, polypropylene meshes and chitosan slabs were ineffective for the correction of penile deviation in bulls. The chitosan slabs showed lower antigenicity to the receptor tissue than the polypropylene meshes since the inflammatory reaction was mild and eosinophil and giant cell infiltrations were not observed in the histological analysis, providing material for future studies.

\section{SUMMARY}

Problems in the reproductive tract may result in difficulty or inability to copulate. Premature penile deviation is an important cause of impotency in male bovines. The aim of the study was to perform clinical and histological evaluation of the correction of surgically induced penile deviation in bulls by fixing the penile apical ligament in the tunica albuginea using synthetic or biological implants. Twenty-one animals with normal penile conformation were subjected to surgical induction of penile deviation by excision of a fragment from the penile apical ligament and replacement with a chitosan slab or polypropylene mesh. The scarification of the tunica albuginea was assessed as a control. The results showed that the tested or evaluated surgical techniques were ineffective in penile deviation correction, since all the animals failed to reestablish the normal axis of the penis. However, microscopic exam revealed that the chitosan slabs proved to be less irritating to the receptor tissue. Therefore, the proposed surgical techniques using synthetic or biological implants were ineffective for the correction of induced penile deviation in bulls.

\section{REFERENCES}

Ashdown RR. 2006. Functional, developmental and clinical anatomy of the bovine penis and prepuce. CAB Reviews: Perspectives in Agriculture, Veterinary Science, Nutrition and Natural Resources 21, 1121-1129.

Babensee JE, JM Anderson, LV Mcintire, AG Mikos. 1998. Host response to tissue engineered devices. Adv Drug Deliv Rev 33, 111-139.

Bellón JM, J Buján, LA Contreras, A Hernando, F Jurado. 1994. Macrophage response to experimental implantation of polypropylene prosthesis. Eur Surg Res 26, 46-53.
Cardoso JR, D Eurides, PC Moreira, AC Mendonça, LAF Silva, FOC Silva, VS Cruz. 2010. Morfologia e biometria do ligamento apical do pênis de touros da raça Girolando. Cienc Rural 40, 1759-1764.

Dinsmore RC, WC Calton, SB Harvey, MW Blaney. 2000. Prevention of adhesions to polypropylene mesh in a traumatized bowel model. J Am Coll of Surg 191, 131-136.

Eurides D, M Silva, HE Coelho, EA Contesini. 1994. Implante de borracha de silicone em pênis de bovinos. Estudo experimental. Cienc Rural 24, 545-550.

Eurides D, LRT Bento, LAF Silva, CR Daleck. 2007. Implante de tendão autólogo do músculo flexor superficial dos dedos no reparo de desvio do pênis de bovinos. Braz J Vet Res Anim Sci 44, 415-421.

Eurides D, LAF Silva, CR Daleck, MCS Fioravanti, GF Gonçalves, OC Silva, AB Nardi. 2009. Implante de cartilage auricular autóloga no reparo de desvio de pênis de bovinos. Pesq Vet Bras 29, 258-262.

Fitzgerald TC. 1963. A study of the deviated penis of the bull. Veter Med 915, 130-138.

Harish PKV, RN Tharanathan. 2007. Chitin/chitosan: modifications and their unlimited application potential - an overview. Trends in Food Sci \& Techn 18, 117-131.

Luna LG. 1968. Manual of histologic staining methods of the Armed Forces Institute of Pathology. McGraw-Hill, New York, USA, Pp 197-207.

Mazzini DL, IM Mantovani. 1999. Fechamento da parede abdominal com afastamento parcial das bordas da aponeurose utilizando sobreposição com telas de vicryl e marlex em ratos. Act Cir Bras 14, 28-34.

Parkinson TJ. 2004. Evaluation of fertility and infertility in natural service bulls. Vet $J 168,215-229$.

Paul W, CP Sharma. 2004. Chitosan and alginate wound dressings: a short review. Trends in Biom \& Art Organs 18, 18-23.

Rabelo RE, NM Paulo, LAF Silva, AD Damasceno, MCS Fioravanti, AF Romani, FGST Fernandes, MAM Silva. 2005 a Emprego do centro tendíneo diafragmático homólogo conservado em glicerina a $98 \%$ e em glutaraldeído a $4 \%$ como implante para hernioplastias umbilicais recidivantes em bovinos. Ars Vet 21, 243-250.

Rabelo RE, FJF Sant' ana, NM Paulo, AF Romani, LAF Silva, MAO Viu, CB Alves, CRO Lima, OC Silva. 2005․ Emprego do compósito látex, poliamida e polilisina a $0,1 \%$ na correção cirúrgica de hérnias umbilicais recidivantes em bovinos leiteiros. Acta Sci Vet 33, 169-175.

Rabelo RE, LAF Silva, LAB Brito, OC Silva, MI Moura, CR Deleck, AD Damasceno. 2008. Desmotomia apical experimental em bovinos e efeitos na indução do desvio peniano. Rev Vet e Zootec 15, 312-324.

Ratner BD, SJ Bryants. 2004. Biomaterials: where we have been and where we are going. Ann Rev Biom Eng 6, 41-75.

Richa RVR. 1987. Nuestra experiência em glicerina em el tratamiento de las grandes hérnias ventrales. Rev Med 19, 109-117.

Rodrigues AP, EMS Sanchez, AC Costa, AM Moraes. 2008. The influence of preparation conditions on the characteristics of chitosan-alginate dressings for skin lesions. J App Polym Sci 109, 2703-2710.

Rucker M, MW Laschke, D Junker, C Carvalho, A Schramm, R Mülhaupt, NC Gellrich, MD Menger. 2006. Angiogenic and inflammatory response to biodegradable scaffolds in dorsal skinfold chambers of mice. Biomat 27, 5027-5038.

Spencer WH. 2003. Ophthalmic pathology: an atlas and textbook. WB Saunders, Philadelphia, USA, Pp 498-517.

Steel RGD, JH Torrie. 1980. Principles and procedures of statistics: $a$ biometrical approach. McGraw Hill, New York, USA, Pp 34-47.

Todd R, BR Donoff, T Chiang, MY Chou, A Elovic, GT Gallagher, DT Wong. 1991. The eosinophil as a cellular source of transforming growth factor alpha in healing cutaneous wounds. Am J Pathol 138, 1307-1313. 